(C) В. О. Іванілова

(Вінниця)

\title{
СТРУКТУРНІ ТА СЕМАНТИЧНІ ОСОБЛИВОСТІ РЕАЛІЙ НА МАТЕРІАЛІ ПОВІСТІ М. О. БУЛГАКОВА «СОБАЧЕ СЕРЦЕ»
}

Статтю присвячено вивченню реалій як одиниць лексичного рівня тексту, які традиційно утворюють певні складнощі при перекладі. Матеріалом дослідження $\epsilon$ мовні одиниці на позначення фонових знань, відібрані з тексту повісті М.О. Булгакова «Собаче серце» методом суцільної вибірки. В роботі реалії представлено як основу екстралінгвістично зумовлених типів фонових знань, виокремлено семантичні групи реалій та розглянуті їх структурні особливості.

Ключові слова: фонові знання, реалія, екстралінгвістичний матеріал, безеквівалентна лексика, лексикологія.

\section{В.О. ИВАНИЛОВА. СЕМАНТИЧЕСКИЕ ОСОБЕННОСТИ РЕАЛИЙ ИЗ ПОВЕСТИ}

\section{М.А. БУЛГАКОВА «СОБАЧЬЕ СЕРДЦЕ»}

Статья посвящена изучению реалий как единиц лексического уровня текста, которые традиционно образуют определенные сложности при переводе. Материалом исследования являются лексические единицы на обозначение фоновых знаний, отобранные из текста повести М.А. Булгакова «Собачье сердце» методом сплошной выборки. В роботе реалии представлены как основа экстралингвистические обусловленных типов фоновых знаний, выделены семантические группы реалий и рассмотрены их структурные особенности.

Ключевые слова: фоновые знания, реалия, экстралингвистический материал, безэквивалентная лексика, лексикология.

Коли мова заходить про фонові знання перекладача, очевидним є те, що їх основу складають реалії. Згідно зі словниковими визначеннями, реалії - це предмети матеріальної культури. У лінгвістиці і перекладознавстві реаліями називають слова і вирази, що позначають ці предмети, а також стійкі словосполучення, що містять в собі такі слова. Реалії є національно-специфічними елементами національно-культурного аспекту тексту, і тому вони часто викликають складнощі в процесі перекладу як акту міжмовної і міжкультурної комунікації.

Дві національні культури ніколи не збігаються повністю. Це, у свою чергу, випливає з того, що кожна складається з національних та інтернаціональних елементів, тому необхідно спеціально виділяти і вивчати лексичні одиниці, в яких найбільш яскраво проявляється своєрідність і специфіка національної культури. Особливо гостро роль фонових знань відчувається при читанні перекладів творів художньої літератури, де часто буде мати місце міжмовна (двомовна) комунікація.

Мета статті полягає у вивченні семантико-прагматичних особливостей лексичних одиниць на позначення фонових знань, зокрема реалій.

Матеріалом дослідження стали 226 мовних одиниць на позначення реалій, які було відібрано методом суцільної вибірки з повісті М.О. Булгакова «Собаче серце». 
Робота поглиблено вивчає такі проблеми перекладу, як аналіз безеквівалентної лексики. Практичне застосування результатів роботи можливе при вивченні лексичних та граматичних проблем перекладу.

Незалежно від своєї видової приналежності, кожен твір (художній, науковий або суспільно-політичний) виникає на національному грунті i в тій чи іншій мірі відображає національні проблеми, етнічні риси, включаючись в інтернаціональне духовне життя. Тому одним 3 основних об'єктів лінгвокраїнознавства $є$ реалії, які представляють невід’ємну частину національної специфіки текстів перекладу.

В кожній мові, незалежно від того, до якої групи та сім’ї вона відноситься, існує величезна кількість лексики на позначення реалій інших лінгвокультурних спільнот, які відрізняються своєю формою, лексичними та морфологічними особливостями. Саме тому перед лінгвістами неминуче постає питання про необхідність впорядковування реалій та створення класифікацій, які базуються на різних підходах до визначення самого терміну «реалія».

Згідно з визначенням, яким послуговується Щерба Л. В., реалія - це предмет, поняття, явище, характерне для історії, культури, побуту, укладу того чи іншого народу країни, що не зустрічається в інших народів; це слово або словосполучення (зазвичай фразеологізм , прислів’я, приказка), що позначає такий предмет, поняття, явище.

Термін «реалія» в якості знака реалії отримав в лінгвістичній літературі досить широке використання. Питання вивчення реалій розглядалися в роботах таких лінгвістів, як М.Л.Вайсбурд, С.М.Верещагін, В.Г.Костомаров, В.Н.Коміссаров, С. І. Влахов, С. Флорін, Л. М. Соболев.

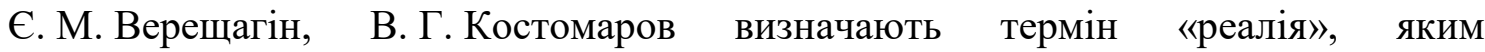
позначаються побутові і специфічні національні слова i звороти, що не мають еквівалентів у побуті, а отже, і в мовах інших країн, та слова з національного побуту, яких немає в інших мовах, тому що немає цих предметів і явищ в інших країнах.

На думку М.Л. Вайсбурд, до числа реалій відносяться події суспільного і культурного життя країни, назви громадських організацій та установ, звичаї та традиції, різноманітні витвори мистецтва, літературні твори, назви предметів побуту, найменування географічних пунктів, імена історичних або громадських діячів, вчених, письменників, композиторів, артистів, популярних спортсменів, персонажів художніх творів, явища природи (в останньому випадку реалії носять регіональний характер), а також безліч розрізнених факторів, що не піддаються класифікації. 
Іванілова В.О. Структурні та семантичні особливості реалій на матеріалі повісті М. О. Булгакова "Собаче серие»

Визначення реалій М. Л. Вайсбурд видається нам найбільш доцільним для дослідження реалій в перекладознавстві, оскільки воно дозволяє залучити до аналізу більше мовних одиниць лінгвокраїнознавчого характеру, тим самим даючи можливість повніше розкрити суть тексту оригіналу при перекладі.

В реаліях найбільш наочно проявляється близькість між мовами і культурою: поява нових реалій в матеріальному і духовному житті суспільства веде до їх номінації в мові, причому час появи неологізму можна встановити досить точно. Так, лексика чуйно реагує на всі зміни суспільного життя. Наприклад, в російській мові реалія «дом отдыха» з’'явилася в 1921 році, «субботник» - в 1919 році, «ударник» - в 1929, «цилинник» - в 1955.

В порівнянні з іншими словами, відмінною рисою реалії є характер ії предметного змісту, тобто тісний зв'язок предмета, поняття, явища 3 народом, країною з одного боку, і історичним відрізком часу - 3 іншого. Звідси випливає, що реаліям притаманний відповідний національний колорит, який робить 3 нейтральної, «неокрашенної» одиниці «національно-забарвлену» реалію. Колорит - це та забарвленість слова, якої воно набуває завдяки приналежності його референта до даного народу, певної країни або місцевості, конкретної історичної епохи.

Вивчення будь-якого мовного явища полягає в тому числі і у відмежуванні його від суміжних понять. Розглянемо поняття, близькі до реалій.

Локалізм (місцеве слово, провінціалізм) - це «слово (або вираз), вживання якого обмежене якоюсь конкретною областю, містом і т.п. і яке не входить до літературного пласту цієї мови» (Ахманова, 1969). Вживання цього терміна як синоніма реалії, 3 одного боку, зміщує їі значення як лексичної одиниці, наближаючи до позначення стилістичної характеристики, а з іншого боку, якщо допустити, що локалізм стоїть в одному ряду з таким словом, як екзотизм, сильно звужує уявлення про дійсний зміст поняття: віднести його можна було б лише до незначної групи реалій, що позначають «місцеві предмети», але позбавлені національного або історичного колориту.

Поняття пробіл або лакуна відноситься до випадків, коли ситуації, звичайні для культури одного народу, не спостерігаються в іншій культурі. В лінгвістиці виділяють повну та неповну лакунарність.

Повною лакунарністю С. Д. Філатов називає «відсутність лексичної одиниці, що позначає те чи інше поняття в лексичній системі літературної мови або його різновиди при зіставленні з іншими його територіальними різновидами» (Філатов, 1983). Якщо у певної кількості запозичених найменувань, які поповнили систему мови, проявляються 
синонімічні фразеологічні одиниці, що дають додаткову конотативну або коннотативно-номінативну інформацію, то мова йде про неповні лакуни.

Варваризми - це іноземні слова або вирази, не до кінця освоєні мовою, в яку вони були запозичені, найчастіше у зв’язку з невідповідністю в граматичному складі мови. Зазвичай варваризми використовуються при описі чужоземних звичаїв та побуту для відтворення місцевого колориту. Реалії, на відміну від варваризмів, по-перше, можуть бути не запозиченими словами, а по-друге, вони не обов'язково є чужими для мови за своєю структурою. Так що реалії можуть бути варваризмами, а можуть і не бути ними.

Екзотична лексика - це слова і вирази, запозичені з інших, часто маловідомих, мов, які вживаються для надання мові особливого (місцевого) колориту. Цей термін можна назвати найбільш серйозним «конкурентом» терміна «реалія» в спеціальній літературі. В той же час, його значення недостатньо сформувалося, і тому в значенні «екзотичної лексики» нерідко вживається термін «варваризм», або серед варваризмів іноді виділяються екзотизми як вид.

Не тільки нестійкість і можливість змішування 3 «варваризми», а й вузькість значення робить термін «екзотизм» в значенні реалії неприйнятним. Екзотизм, подібно варваризму, є тільки іншомовним словом, але, на відміну від варваризму, це слово, вже увійшло в лексику відповідної мови, тоді як реалії можуть бути свого роду оказіоналізмами, до того ж, до екзотизмів традиційно не включають історичні реалії, розглядаючи лексичні одиниці тільки з точки зору місцевої приналежності.

Термін «безеквівалентна лексика» зустрічається у багатьох авторів, які трактують його по-різному: як синонім реалій, у ширшому значенні - як слова, «відсутні в іншій культурі і іншій мові» (Верещагін, Костомаров, 1980), у вузькому значенні - як слова, характерні для певної культурної дійсності, і нарешті, просто як слова, які неможливо перекласти іншою мовою. Реалія відрізняться від безеквівалентної лексичної одиниці тим, що слово може бути реалією по відношенню до всіх або більшості мов, а безеквівалентною лексикою - переважно в рамках окремо взятої пари мов. Це означає, що список реалій конкретної мови буде більш-менш постійним, у той час як словник безеквівалентної лексики виявиться різним для різних пар мов.

3 усього вищевикладеного можна зробити висновок, що реалії - це особлива категорія засобів вираження. Реаліями слід вважати слова і словосполучення, які називають об'єкти, характерні для життя (побуту, культури, соціального і історичного 
розвитку) одного народу і чужими для іншого етносу. Вони є носіями національного і історичного колориту і не мають, як правило, точних відповідностей (еквівалентів) в інших мовах.

Необхідність класифікації реалій, зумовлена тим, що вона, по-перше, дає можливість охарактеризувати цей специфічний пласт лексики і дати йому визначення; по-друге, вона сприяє більш вірному вирішенню питань, пов'язаних 3 перекладом реалій з однієї мови на іншу, тому що місце, яку займає конкретна реалія в класифікації, може показати перекладачеві ступінь їі важливості для того чи іншого контексту.

Детальна класифікація реалій, яку запропонували С. Влахов і С. Флорін, дозволяє розглядати реалії з різних точок зору, а також розділити їх за конотативним значенням.

3 погляду предметного поділу, реалії діляться на географічні, етнографічні та суспільно-політичні.

Географічні реалії пов’зані з фізичною географією і ї̈ розділами. У цю групу входять назви об'єктів фізичної географії та метеорології, назви географічних об’єктів, пов'язаних з людською діяльністю, назви ендеміків.

Етнографічні реалії пов'язані з етнографією, наукою, що вивчає побут і культуру народів, форми матеріальної культури, звичаї, релігію. Ці реалії включають в себе реалії, пов'язані з побутом (назви їжі та напоїв, одягу, житла, посуду і начиння, транспорту та ін.), реалії, пов'язані з працею (люди праці, знаряддя праці, організація праці), реалії, пов'язані з мистецтвом і культурою (музика, танці, музичні інструменти, фольклор, театр, звичаї та ритуали, свята, міфологія, культи, календар), реалії, пов'язані з етнічними об’єктами (етноніми, клички, назви осіб за місцем проживання), реалії, що позначають міри та гроші.

Суспільно-політичні, соціально-економічні та військові реалії $\epsilon$ реаліями законодавчої та виконавчої влади, судової та виборчої системи і позначають назви соціальних верств, класів, станів та ін. Сюди входять реалії, пов'язані 3 адміністративно-територіальним устроєм (адміністративно-територіальні одиниці, населені пункти, деталі населеного пункту), реалії, пов’язані з органами і носіями влади, реалії, пов'язані з суспільно-політичним життям (політична діяльність і діячі, громадські рухи, соціальні явища та рухи, звання, ступені, титули, звернення, установи, навчальні заклади, касти), військові реалії (підрозділи, зброя, обмундирування, військовослужбовці). 
Крім цього, вважається за доцільне включити в семантичну класифікацію реалій імена історичних персоналій, такі як Николай Романов, Карл Маркс, Айседора Дункан, профессор Мечников, Спиноза, Менделеев, Энгельс. Імена історичних діячів $\epsilon$ надзвичайно важливим елементом екстралінгвістичного матеріалу, тому що без них неможливо повністю відобразити стилістичне забарвлення першотвору. Але, не всі лінгвісти визначають антропоніми як реалії. Тематична класифікація реалій, розроблена С. Влаховим і С. Флоріним не передбачає внесення імен історичних діячів до складу реалій. Спираючись на визначення М. Л. Вайсбурд, ми все ж схильні до того, щоб вважати антропоніми реаліями, тому що вони позначають людину, місце якої зафіксовано в конкретний історичний період, і характеризують саме цей період, незалежно від того, в якому контексті вони вживаються.

Матеріалом дослідження стали 226 реалій. 3 точки зору структурного поділу, найчастіше до реалій відносять слова, лексичні одиниці і словосполучення, які семантично рівні слову. Говорячи про фразеологічні одиниці, потрібно сказати, що реаліями вважаються як звичайні стійкі словосполучення всіх типів (ідіоми, прислів’я, приказки), так і фразеологічні одиниці, складовим компонентом якого є реалія. Особливою формою реалій $є$ скорочення, оскільки вони являють собою цілісні номінативні поєднання.

В цьому дослідженні використовувалася структурну класифікацію реалій М. Л. Вайсбурд. На їі думку, поняття, що відноситься до числа реалій, можуть бути виражені окремими словами, словосполученнями, реченнями, скороченнями.

Результати класифікації реалій з точки зору їх структури представлено в Таблиці 1.

Таблиия 1

Структурна класифікація реалій в повісті М.О. Булгакова «Собаче серце»

\begin{tabular}{|l|l|l|l|}
\hline \multicolumn{1}{|c|}{ № } & \multicolumn{1}{|c|}{ Структурний тип } & \multicolumn{2}{c|}{ Кількість } \\
\hline & \multicolumn{1}{|c|}{ Число } & $\%$ \\
\hline 1. & Одне слово & 134 & 59 \\
\hline 2. & Сполучення слів & 76 & 34 \\
\hline 3. & Речення & 7 & 3 \\
\hline 4. & Скорочення & 9 & 4 \\
\hline & Усього & 226 & 100 \\
\hline
\end{tabular}

Найчастіше в повісті реалії виражаються одним словом (пролетарий, пятиалтынный, позумент, кубарь, домоуправление, большевик, буржуй, клобук, примус, балалайка), більшість з яких представлена іменниками. Але, в межах відібраного матеріалу зустрічаються також прикметники (беспартийный, городовой) та дієслово (расписаться). Продуктивність іменників-реалій імпліцитно закладена у саму 
Іванілова В.О. Структурні та семантичні особливості реалій на матеріалі nовісті М. О. Булгакова "Собаче серие»

дефініцію останніх, виходячи з якої логічним є те, що найчастіше реалії виражаються окремими словами, переважно іменниками, адже найчастіше реалія називає предмет, відсутній в культурній дійсності іншого народу, а для номінації предметів або явищ в будь якій мові слугують саме іменники.

Друга за величиною група складають з реалії, виражені сполученнями слів, як сталими, так і вільними (Вільні: Дом жилищного товарищества, уплотнение квартир, колчаковский фронт. Сталі: бельй террор, красный террор, , нечистый дух, бельій билет, ияарский режим, краснылй командир). У цьому випадку, більшість реалій є іменниковими словосполученнями.

Наступною групою є реалії, виражені скороченнями, такі як домком, культотдел, РСФСР, МСПО, Москшвея. Незважаючи на невелику кількість, такі лексичні одиниці надзвичайно успішно передають дух епохи, в якій відбувається дія повісті «Собаче серце». В радянські часи скорочення були дуже поширеними i використовувалися у повсякденному спілкуванні.

Найменш чисельною є група реалій, представлених реченнями. Прикладами цієї групи виступають: ...калачом не виманишь; ияарство ему небесное; ... и ешь его с камей. Такого типу реалії здебільшого являються фразеологічними одиницями і використовуються для надання стилістичного забарвлення тексту. Найчастіше вони зустрічаються в діалогах, як складові частини мовлення героїв для ілюстрації реальності, в якій вони існують в повісті та екстралінгвістичної інформації стосовно їх соціального статусу, політичних переконань, емоційного стану, тощо.

3 точки зору семантичних особливостей, в повісті М. О. Булгакова «Собаче серце» найбільш уживаною категорією є реалії, які позначають предмети або явища, пов'язані з побутом: краковская, позумент, галун, самовар, передняя, кубарь, папаха, примус, ииш с маслом; дом жилищного товарищества.

Наступні за числьністтю прикладів семантичні групи - це реалії, пов'язані 3 суспільно-політичним життям: пролетарий, барин, гражданин, господин, товарищ, большевик, помещчик, буржуй, меньшевик; ияарский режим, мировая револючия уплотнение квартир, красный террор, белый террор та реалії, пов'язані з культурою та мистецтвом: Большой, епитрахиль, клобук, балалайка, леший, пасквиль, ... загробной жизни не существует; нечистый дух.

Досить велика кількість мовних одиниць представлена в категорії реалій, пов'язаних 3 працею: извозчик, городовой, Моссельпром, культотдел, отдел МХК, рабочий кредит, давать на чай. Автор активно використовує топоніми, які входять до 
складу реалій, пов'язаних 3 адміністративно-територіальним устроєм:

Пречистенка, Неглинный, Сокольники, Сухаревка, Холмогоры, РСФСР, Преображенская застава, Смоленский рынок, Моховая улища, Мясниџкая улица, Обухов переулок, Охотный ряд.

В тексті повісті також можна зустріти реалії, які називають органи чи носіїв влади, наприклад, домоуправление, председатель, заведующий, МСПО, домком, Центральный совет народного хазяйства та військові реалії: Колчаковский фронт, красный командир, бельій билет, взять на воинский учет.

Найменш чисельна група реалій - та, що позначає етнічні об'скти. Туди входять лише дві лексичні одиниці: немщь, мосье. Семантична група «Ендеміки» представлена лише трьома мовними одиницями: индийский петух, черно-бурая лиса, «под сибирского деланный» Такі групи, як «об'єкти фізичної географії» та «географічні об’скти пов'язані з людиною» взагалі не представлені в повісті.

Статистичні результати вивчення матеріалу з точки зору його відношення до різних семантичних груп зображено в Таблиці 2.

Таблиия 2

Семантична класифікація реалій в повісті М.О. Булгакова «Собаче серце»

\begin{tabular}{|c|c|c|c|c|}
\hline \multirow[t]{2}{*}{ № } & \multicolumn{2}{|r|}{ Семантичні групи } & \multicolumn{2}{|c|}{ Кількість } \\
\hline & & & Число & $\%$ \\
\hline \multirow[t]{3}{*}{1.} & \multirow{3}{*}{$\begin{array}{l}\text { Географічні } \\
\text { реалії }\end{array}$} & Назви об’єктів фізичної географії та метеорології & - & - \\
\hline & & $\begin{array}{l}\text { Назви географічних об'єктів, пов'язаних } 3 \\
\text { людиною }\end{array}$ & - & - \\
\hline & & Ендеміки & 3 & 1,4 \\
\hline \multirow[t]{3}{*}{2.} & \multirow{3}{*}{$\begin{array}{l}\text { Етнографічні } \\
\text { реалії }\end{array}$} & Пов’язані з побутом & 82 & 36,3 \\
\hline & & Пов’язані з працею & 28 & 12,7 \\
\hline & & Пов’язані з мистецтвом і культурою & 37 & 15,9 \\
\hline \multirow[t]{2}{*}{3.} & & Етнічні об’єкти & 2 & 0,9 \\
\hline & & Міри і грощі & 8 & 3,6 \\
\hline \multirow[t]{5}{*}{4.} & \multirow[t]{4}{*}{$\begin{array}{l}\text { Суспільно- } \\
\text { політичні реалії }\end{array}$} & $\begin{array}{l}\text { Пов’язані з адміністративно-територіальним } \\
\text { устроєм }\end{array}$ & 14 & 6,3 \\
\hline & & Органи та носії влади & 7 & 3 \\
\hline & & Пов'язані з суспільно-політичним життям & 39 & 17,2 \\
\hline & & Військові реалії & 6 & 2,7 \\
\hline & \multicolumn{2}{|l|}{ Усього } & 226 & 100 \\
\hline
\end{tabular}

Переважання реалій, які позначають предмети або явища, пов'язані з побутом та реалій, пов'язаних з суспільно-політичним життям, можна пояснити бажанням автора в повній мірі відтворити історичну дійсність, яка оточувала його самого та персонажів повісті. Михайло Опанасович Булгаков народився 3 травня 1891 року, тому йому, на власні очі довелося побачити, що діялося в країні під час та після революції. Як представник інтелігенції, син богослова, він також чітко розумів, як нова влада 
Іванілова В.О. Структурні та семантичні особливості реалій на матеріалі повісті М. О. Булгакова «Собаче серие»

відноситься до його верстви суспільства, надаючи перевагу робочому класу, який допоміг їм взяти під контроль усі ключові пости. Герої повісті «Собаче серце» говорять те, що через відомі російськомовному читачу обставини не міг сказати автор, томуі існувати вони повинні в тих самих умовах, в яких жили люди в Росії на початку XX століття.

3 іншого боку, майже повна відсутність реалій, що позначають етнічні об'єкти, яскраво ілюструє прагнення радянських лідерів створити єдиний радянський народ, стерши не тільки кордони між складовими частинами Радянського Союзу, але й окремі еконізми, яки використовуються для номінації відповідних народів.

Цікавим $є$ те, що для позначення грошей автор використовує цілих 7 реалій рубль, червонеи, пятиалтынный, копейка, золотник, двугривенный, целковый. Це зумовлено тим, що в радянські часи в розмовній російській мові одночасно використовувалися декілька лексичних одиниць, які відносилися до різних пластів мови, наприклад рубль був офіційною назвою державної валюти СРСР, пятиалтынныий позначав сумму в 15 копійок. Спроба карбування такої срібної монети була вперше зроблена в Росії за часів правління Слизавети Петрівни з наміром створити розмінний номінал, проміжний між гривеником (10 копійок) і четвертаком (25 копійок). Назва «золотник», ймовірно, походить від назви маленької золотої монети, що існувала в часи Київської Русі і пізніше. Червонец позначав сумму в 10 рублів, а двугривенный - в 20 копійок. Знання про специфічну номінації грошових одиниць потрібні перекладачу для відтворення дійсності, зображеної в тексті оригіналу, в перекладі, щоб не спотворювати концепцію твору, яку сприймає читач, який, в свою чергу, є носієм мови перекладу.

То ж структурна класифікація реалій з тексту повісті М. О. Булгакова «Собаче серце» показала, що більшість уживаних в тексті реалій виражаються одним словом і $є$ іменниками (134 одиниці або 59\%). Рідше за все зустрічаються реалії, представлені цілими реченнями (7 одиниць або 3\%). Найчастіше такі реалії виражаються фразеологічними одиницями. Семантична класифікація реалій, запропонована С. Влаховим та С. Флоріним дозволяє зробити висновок про те, що найчастіше за усе у тексті повісті М. О. Булгакова «Собаче серце» вживаються реалії, пов'язані з побутом (82 одиниці або 36,3\%). Найменш уживаною групою є реалії, які позначають етнічні об'єкти (2 або 0,9\%). 


\section{СПИСОК ЛІТЕРАТУРИ} 1969.

1. Ахманова О. С. Словарь лингвистических терминов - М. : Советская энциклопедия, $256 \mathrm{c}$.

2. Булгаков М. А. Собачье сердце: повести / СПб. : Азбука, Азбука-Аттикус, 2015. -

3. Вайсбурд М. Л. Реалии как элемент страноведения // РЯзР. - 1972. - № 3. - С. 98-100. я3., 1980

4. Верещагин Е. М. Костомаров В. Г. Лингвострановедческая теория слова - М. : Рус.

5. Влахов C., Флорин С. Непереводимое в переводе - М. : Международные отношения, 1980. $-343 \mathrm{c}$.

6. Комиссаров В. Н. Современное переводоведение. Учебное пособие. - М. : ЭТС. 2002.- $424 \mathrm{c}$.

7. Нелюбин Л. Л. Лингвостилистика современного английского языка. Изд. 3-е, перераб. и доп. М. : МОПИ, 1990. $-110 \mathrm{c}$.

8. Новикова Н. C., Черемшина Н. В. Многомирие в реалии и общая типология языковых картин мира. // Филол. Науки, 2000. - С. 52-53

9. Ромова О.М. Понятие «реалия» в ряду других научных терминов в лингвистике // Вестник Московского государственного областного университета. Серия: Лингвистика. 2010. № 2. C. 60-63.

10. Фененко Н. А. Язык реалий и реалии языка. - Воронеж : Изд-во ВГУ, 2001. - 139 с.

11. Филатов В. Д. Локальная маркированность фразеологических единиц // МГПИИЯ сборник научных трудов. Вып. 212. - М., 1983.

12. Щерба Л. В. Опыт общей теории лексикографии // Избранные работы по языкознанию и фонетике. Т. 1. Л., 1958. С. 54-91. 